\title{
Megaloblastic anemia-related iron overload and erythroid regulators: a case report
}

\author{
Nicolas Vallet ${ }^{1}$, Jean-Baptiste Delaye ${ }^{2}$, Martine Ropert ${ }^{3}$, Amélie Foucault ${ }^{4,5}$, Noémie Ravalet ${ }^{4,5}$, Sophie Deriaz ${ }^{6}$, \\ Thomas Chalopin ${ }^{1}$, Hélène Blasco ${ }^{2}$, François Maillot ${ }^{6}$, Olivier Hérault ${ }^{4,5}$ and Emmanuel Gyan ${ }^{1,5^{*}}$
}

\begin{abstract}
Background: In ineffective erythropoiesis, hepcidin synthesis is suppressed by erythroid regulators, namely erythroferrone and growth differentiation factor-15. For the first time, the hypothesis that iron overload in megaloblastic anemia may be related to ineffective erythropoiesis is explored by describing the kinetics of hepcidin, erythroferrone, and growth differentiation factor-15 levels in a patient diagnosed with megaloblastic anemia associated with iron overload.

Case presentation: An 81-year-old Caucasian male was admitted for fatigue. He had type-2 diabetes previously treated with metformin, ischemic cardiac insufficiency, and stage-3 chronic kidney disease. Vitiligo was observed on both hands. Biological tests revealed normocytic non-regenerative anemia associated with hemolysis, thrombocytopenia, and elevated sideremia, ferritin, and transferrin saturation levels. Megaloblastic anemia was confirmed with undetectable blood vitamin B12 and typical cytological findings like hyper-segmented neutrophils in blood and megaloblasts in bone marrow. The patient received vitamin B12 supplementation. At 3 months, biological parameters reached normal values. Hepcidin kinetics from diagnosis to 3 months inversely correlated with those of erythroferrone and growth differentiation factor-15.
\end{abstract}

Conclusions: This case suggests that iron-overload mechanisms of dyserythropoietic anemias may apply to megaloblastic anemias.

Keywords: Vitamin B12, Iron overload, Erythropoiesis, Erythroferrone, GDF15, Case report

\section{Background}

Iron overload related to hemolysis and ineffective erythropoiesis is a feature of megaloblastic anemia. The latter mechanism is yet to be explored [1,2]. In ineffective erythropoiesis, hepcidin synthesis is suppressed by erythroid regulators, namely erythroferrone (ERFE) [3] and growth differentiation factor-15 (GDF15) [4]. Hepcidin is essential for iron homeostasis, as it induces the endocytosis of ferroportin, lowering iron absorption and circulating iron levels through iron sequestration by

\footnotetext{
*Correspondence: emmanuel.gyan@univ-tours.fr

${ }^{1}$ Department of Hematology and Cell Therapy, Tours University Hospital, 2 Boulevard Tonnellé, 37044 Tours Cedex, France

Full list of author information is available at the end of the article
}

hepatocytes, macrophages, and duodenal enterocytes [5]. Herein, we describe the kinetics of hepcidin, ERFE, and GDF15 levels in a patient diagnosed with megaloblastic anemia associated with iron overload. We hypothesized that ineffective erythropoiesis was associated with high levels of ERFE and GDF15 at the time of diagnosis, possibly associated with suppressed hepcidin, thus explaining the iron overload.

\section{Case presentation}

An 81-year-old Caucasian male was referred to emergency department for fatigue associated with profound anemia. He had type-2 diabetes previously treated with metformin, ischemic cardiac insufficiency, and stage-3 chronic kidney disease (CKD, CKD-Epidemiology original author(s) and the source, provide a link to the Creative Commons licence, and indicate if changes were made. The images or other third party material in this article are included in the article's Creative Commons licence, unless indicated otherwise in a credit line to the material. If material is not included in the article's Creative Commons licence and your intended use is not permitted by statutory regulation or exceeds the permitted use, you will need to obtain permission directly from the copyright holder. To view a copy of this licence, visit http://creativecommons.org/licenses/by/4.0/. The Creative Commons Public Domain Dedication waiver (http://creativeco mmons.org/publicdomain/zero/1.0/) applies to the data made available in this article, unless otherwise stated in a credit line to the data. 
Collaboration [CKD-EPI] estimated glomerular filtration rate: $32 \mathrm{~mL} /$ minute $/ 1.73 \mathrm{~m}^{2}$ ). There were no clinical signs of infectious or tumoral disease. Vitiligo was observed on both hands. First biological tests revealed normocytic non-regenerative anemia associated with hemolysis, thrombocytopenia, and elevated sideremia, ferritin, and transferrin saturation (TSAT) levels. Vitamin B12 was undetectable, whereas vitamin B9 and C-reactive protein levels were normal (Table 1). He received one pack of red blood cells (RBC), then was admitted to internal medicine department. A peripheral blood smear showed hypersegmented neutrophils, and a bone-marrow smear showed hypercellularity and clear signs of dyserythropoiesis and blocked maturation of erythroid cells (Fig. 1a, b). Stomach endoscopy and biopsies showed chronic gastritis and fundic atrophy. Though metformin may have participated in this condition [1], a diagnosis of megaloblastic anemia caused by pernicious anemia was preferred considering the profound anemia and vitiligo, even if blood antiparietal cells or anti-intrinsic-factor antibodies were not detected. After two other packs of $\mathrm{RBC}$ and five daily intramuscular vitamin B12 injections, he was discharged and continued oral vitamin B12 supplementation. Three-month (M3) biological control revealed that platelet count and hemoglobin, sideremia, and TSAT levels normalized (Table 1). Ferritin returned to normal values at 7 months $(361 \mu \mathrm{g} / \mathrm{L})$.

We tested our hypothesis by analyzing the samples at the time of diagnosis and at M3 after receiving informed consent of the patient. Serum hepcidin, ERFE, and GDF15 levels were assessed by ELISA (hepcidin-25: S-1337, Peninsula; ERFE: ERF-001, Intrinsic LifeSciences; GDF15: DGD150, R\&D Systems). Serum erythropoietin (EPO) was measured by chemiluminescence (UniCel DxL, Beckman Coulter).

ERFE and GDF15 levels were higher than those of age-matched healthy controls (HC) at diagnosis, dropping to $\mathrm{HC}$ levels at $\mathrm{M} 3$, supporting our hypothesis. The level of hepcidin was lower at the time of diagnosis than M3 but remained within reference levels, and its kinetics from diagnosis to M3 inversely correlated with those of EPO, ERFE, and GDF15 (Table 1).

Table 1 Peripheral blood characteristics at diagnosis and 3 months after vitamin B12 supplementation

\begin{tabular}{|c|c|c|c|c|}
\hline Biological parameters & Unit & At diagnosis & 3 months later & $\begin{array}{l}\text { Laboratory } \\
\text { reference } \\
\text { range }\end{array}$ \\
\hline Hemoglobin & $g / L$ & 57 & 129 & $129-170$ \\
\hline Mean corpuscular volume & $f L$ & 99 & 90 & $80-100$ \\
\hline Reticulocytes & $10^{9} / \mathrm{L}$ & 16 & 94 & NA \\
\hline Absolute neutrophil count & $10^{9} / \mathrm{L}$ & 2.2 & 5.4 & $1.5-7.5$ \\
\hline Platelets & $10^{9} / \mathrm{L}$ & 89 & 240 & $150-400$ \\
\hline Creatinine & $\mu \mathrm{mol} / \mathrm{L}$ & 171 & 200 & 59-104 \\
\hline $\begin{array}{l}\text { Estimated glomerular filtration rate (CKD-EPI } \\
\text { formula) }\end{array}$ & $\mathrm{mL} /$ minute $/ 1.73 \mathrm{~m}^{2}$ & 32 & 26 & NA \\
\hline Total bilirubin & $\mu \mathrm{mol} / \mathrm{L}$ & 31 & 9 & $2-24$ \\
\hline Indirect bilirubin & $\mu \mathrm{mol} / \mathrm{L}$ & 20 & 5 & $2-17$ \\
\hline Haptoglobin & $g / L$ & 0.4 & 1.8 & $0.5-2.0$ \\
\hline Lactate dehydrogenase & $U / L$ & 910 & 164 & $135-225$ \\
\hline Sideremia & $\mu \mathrm{mol} / \mathrm{L}$ & 36 & 13 & $5.8-34.5$ \\
\hline Ferritin & $\mu g / L$ & 537 & 437 & $30-400$ \\
\hline Transferrin & $g / L$ & 1.60 & 2.10 & $2.0-3.6$ \\
\hline Transferrin saturation coefficient & $\%$ & 88 & 25 & $25-40$ \\
\hline Reactive $C$ protein & $\mathrm{mg} / \mathrm{L}$ & 1.2 & 0.9 & $0.3-5.0$ \\
\hline Vitamin B9 & $\mathrm{nmol} / \mathrm{L}$ & 21 & - & $8.8-60.8$ \\
\hline Vitamin B12 & $\mathrm{pmol} / \mathrm{L}$ & $<111$ & 743 & $145-569$ \\
\hline Erythropoietin & $\mathrm{mUl} / \mathrm{mL}$ & 43.9 & 8.6 & $2.6-18.5$ \\
\hline GDF15 & $\mathrm{pg} / \mathrm{mL}$ & $>8000$ & 2,240 & $1080-3700^{*}$ \\
\hline Erythroferrone & $\mathrm{ng} / \mathrm{mL}$ & 14.44 & 0.53 & $0.01-1.92^{*}$ \\
\hline Hepcidin $^{\dagger}$ & $\mathrm{nmol} / \mathrm{L}$ & 10.6 & 28.7 & $4-30$ \\
\hline
\end{tabular}




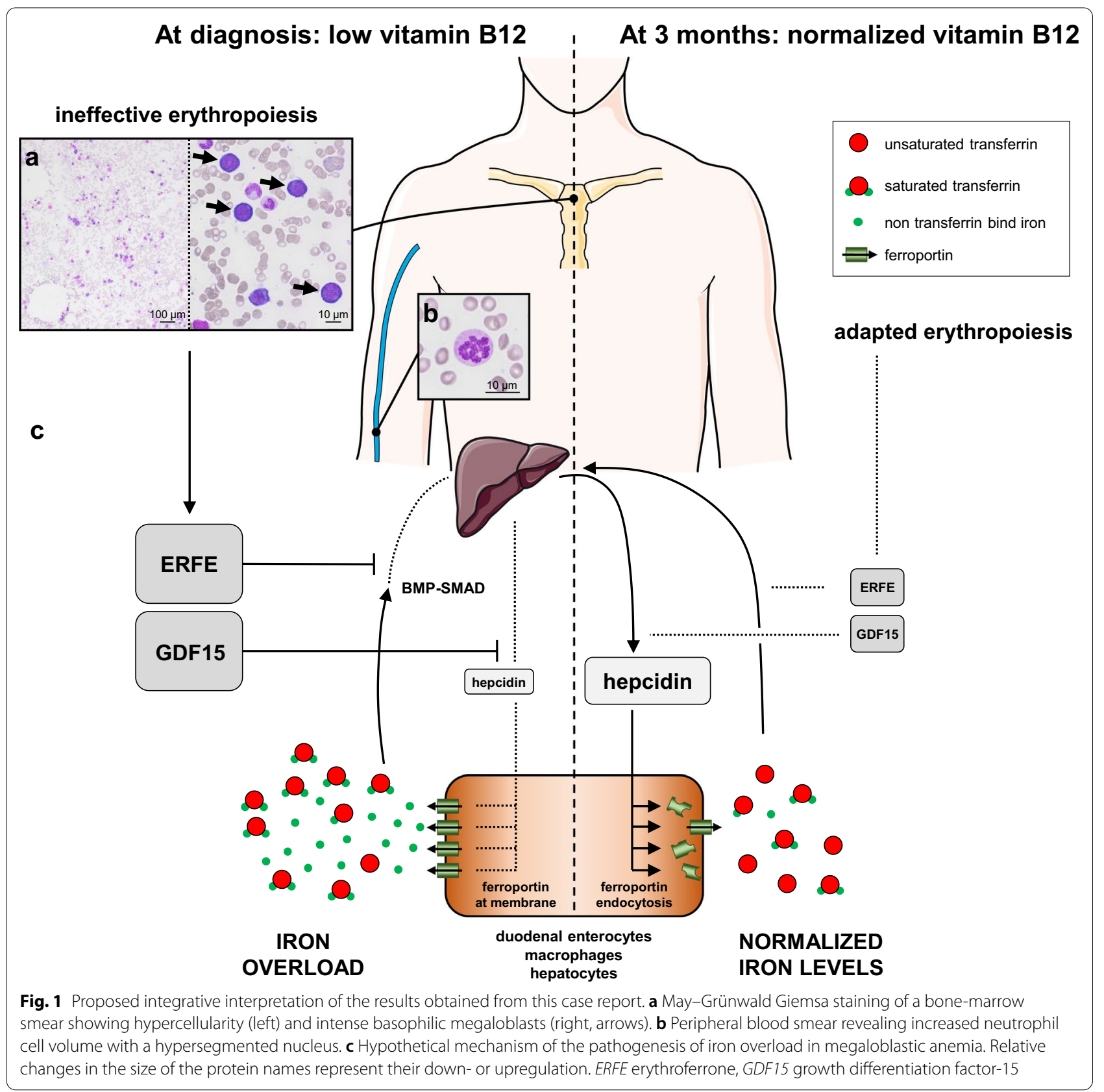

\section{Discussion and conclusions}

Given the high level of TSAT, the level of hepcidin at diagnosis was inappropriately low, suggesting suppression by an erythroid regulator. The influence of CKD $[6,7]$ and metformin [8] may explain why the hepcidin levels were comparable to those of $\mathrm{HC}$, but its range is consistent with that found in CKD patients [7]. A metabolic syndrome may also explain high ferritin levels. But these potential biases were internally controlled by comparing two time points before and after vitamin B12 and hemoglobin normalization, when comorbidities and treatments were comparable. ERFE and GDF15 levels were higher than in $\mathrm{HC}$ from our institution and previous studies $[9,10]$. ERFE levels at diagnosis were comparable to those of patients with pyruvate-kinase deficiency but lower than those with $\beta$-thalassemia [9]. The inverse correlation of EPO and ERFE kinetics is consistent with that observed in EPO-treated healthy humans [3] and CKD mouse [6] models. The GDF15 level at diagnosis was comparable to that of congenital dyserythropoietic 
anemia type-1 [11]. Despite the undetectable vitamin B12 levels and typical cytological abnormalities that define megaloblastic anemia, the mean corpuscular volume (MCV) was unexpectedly not macrocytic [1]. The patient had no history of iron deficiency, inflammation, or red-blood-cell transfusion. GDF15 was recently shown to stimulate erythroid precursor growth in mice [12]. Cell-cycle acceleration in erythroid precursors may have hidden macrocytosis, but whether high levels of GDF15 may have affected the MCV remains to be demonstrated. Intramedullary hemolysis, suggested by bilirubin, lactate dehydrogenase, and haptoglobin levels, can also explain iron overload [2]. However, hemolysis alone cannot explain the higher ERFE and GDF15 levels. In sickle-cell diseases (SCD), in which hemolysis is dominant compared with dyserythropoiesis, the ERFE and GDF15 levels and their correlation with hepcidin levels were not comparable to those observed in $\beta$-thalassemia [13]. Additionally, the hepcidin level was inappropriately low relative to that at M3 when TSAT was normal, reinforcing the hypothesis that an erythroid regulator suppressed hepcidin synthesis.

ERFE suppresses hepcidin synthesis by sequestering bone morphogenetic protein (BMP) receptor ligands [5]. Its synthesis starts upon EPO stimulation through the JAK2-STAT5 pathway in erythroblasts [14]. ERFE levels are elevated in human congenital or acquired dyserythropoietic diseases associated with iron overload [3, 15]. GDF15 was shown to suppress hepcidin synthesis in the context of $\beta$-thalassemia [4] and congenital dyserythropoietic anemia [11]. GDF15 is produced by erythroblasts, but its mechanisms of synthesis and hepcidin suppression are not fully understood $[4,10]$.

In conclusion, we found the kinetics of hepcidin, ERFE, and GDF15 to be comparable to those described in iron overload associated with ineffective erythropoiesis (Fig. 1c). This case broadens the spectrum of ironoverload mechanisms in dyserythropoietic anemias to vitamin B12 deficiency, in which hepcidin levels inversely correlate with those of erythroid regulators, suggesting suppression by ERFE and GDF15.

\section{Abbreviations}

BMP: Bone morphogenetic protein; CKD: Chronic kidney disease; EPO: Erythropoietin; ERFE: Erythroferrone; GDF15: Growth differentiation factor-15: M3: Three months; MCV: Mean corpuscular volume; RBC: Red blood cells; SCD: Sickle cell disease; TSAT:Transferrin saturation.

\section{Acknowledgements}

Fig. 1 was created using illustrations from Servier Medical Art by Servier, licensed under a Creative Commons Attribution 3.0 Unported License. http:// smart.servier.com.

\section{Authors' contributions}

EG and NV designed the study and wrote the paper. JBD designed the study and performed the ERFE and GDF15 assays. MR performed the hepcidin assays, and AF performed the cytological analysis. All authors critically reviewed the paper, and read and approved the final version of the manuscript.

\section{Funding}

Not applicable

\section{Availability of data and materials}

The dataset analyzed during the current study is available from the corresponding author on reasonable request.

\section{Declarations}

Ethics approval and consent to participate

Patient and controls gave their consent to participate. Analyses were conducted according to Helsinki declaration.

\section{Consent for publication}

Written informed consent was obtained from the patient for publication of this case report and any accompanying images. A copy of the written consent is available for review by the Editor-in-Chief of this journal.

\section{Competing interests}

The authors declare that they have no competing interests.

\section{Author details}

${ }^{1}$ Department of Hematology and Cell Therapy, Tours University Hospital, 2 Boulevard Tonnellé, 37044 Tours Cedex, France. ${ }^{2}$ Department of Biochemistry and Molecular Biology, Tours University Hospital, Tours, France. ${ }^{3}$ Department of Biochemistry, CHU Rennes, Rennes, France. ${ }^{4}$ Department of Biological Hematology, Tours University Hospital, Tours, France. ${ }^{5}$ CNRS ERL7001 LNOX, EA 3549, Tours University, Tours, France. ${ }^{6}$ Department of Internal Medicine, Tours University Hospital, Tours, France.

Received: 16 December 2020 Accepted: 16 August 2021

Published online: 20 September 2021

\section{References}

1. Green R. Vitamin B12 deficiency from the perspective of a practicing hematologist. Blood. 2017;129(19):2603-11.

2. Ho C-H, You J-Y, Chau W-K, et al. Diagnostic value of serum transferrin receptor and glycosylated hemoglobin on hemolytic anemia. Ann Hematol. 2003;82(4):228-30.

3. Ganz T, Jung G, Naeim A, et al. Immunoassay for human serum erythroferrone. Blood. 2017;130(10):1243-6.

4. Tanno T, Bhanu NV, Oneal PA, et al. High levels of GDF15 in thalassemia suppress expression of the iron regulatory protein hepcidin. Nat Med. 2007:13(9):1096-101.

5. Camaschella C, Nai A, Silvestri L. Iron metabolism and iron disorders revisited in the hepcidin era. Haematologica. 2020;105(2):260-72.

6. Hanudel MR, Rappaport M, Chua K, et al. Levels of the erythropoietinresponsive hormone erythroferrone in mice and humans with chronic kidney disease. Haematologica. 2018;103(4):e141-2.

7. Coll AP, Chen M, Taskar P, et al. GDF15 mediates the effects of metformin on body weight and energy balance. Nature. 2020;578(7795):444-8.

8. Ashby DR, Gale DP, Busbridge M, et al. Plasma hepcidin levels are elevated but responsive to erythropoietin therapy in renal disease. Kidney Int. 2009;75(9):976-81.

9. van Vuren AJ, Eisenga MF, van Straaten S, et al. Interplay of erythropoietin, fibroblast growth factor 23 , and erythroferrone in patients with hereditary hemolytic anemia. Blood Adv. 2020;4(8):1678-82.

10. Theurl I, Finkenstedt A, Schroll A, et al. Growth differentiation factor 15 in anaemia of chronic disease, iron deficiency anaemia and mixed type anaemia. Br J Haematol. 2010;148(3):449-55.

11. Casanovas G, Swinkels DW, Altamura S, et al. Growth differentiation factor 15 in patients with congenital dyserythropoietic anaemia (CDA) type II. J Mol Med. 2011;89(8):811-6. 
12. Hao $S$, Xiang J, Wu D-C, et al. Gdf15 regulates murine stress erythroid progenitor proliferation and the development of the stress erythropoiesis niche. Blood Adv. 2019;3(14):2205-17.

13. Mangaonkar AA, Thawer F, Son J, et al. Regulation of iron homeostasis through the erythroferrone-hepcidin axis in sickle cell disease. Br J Haematol. 2020;189(6):1204-9.

14. Kautz L, Jung G, Valore EV, Rivella S, Nemeth E, Ganz T. Identification of erythroferrone as an erythroid regulator of iron metabolism. Nat Genet. 2014:46(7):678-84.
15. Bondu S, Alary A-S, Lefèvre C, et al. A variant erythroferrone disrupts iron homeostasis in SF3B1-mutated myelodysplastic syndrome. Sci Transl Med. 2019. https://doi.org/10.1126/scitrans/med.aav5467.

\section{Publisher's Note}

Springer Nature remains neutral with regard to jurisdictional claims in published maps and institutional affiliations.
Ready to submit your research? Choose BMC and benefit from:

- fast, convenient online submission

- thorough peer review by experienced researchers in your field

- rapid publication on acceptance

- support for research data, including large and complex data types

- gold Open Access which fosters wider collaboration and increased citations

- maximum visibility for your research: over $100 \mathrm{M}$ website views per year

At BMC, research is always in progress.

Learn more biomedcentral.com/submissions 